\title{
WOLNOŚĆ LUDZKA W UJĘCIU JANA JAKUBA ROUSSEAU
}

\begin{abstract}
Streszczenie. Jan Jakub Rousseau broni wolności człowieka w wymiarze indywidualnym i społecznym. Podstawą wolności jest wolność naturalna, właściwa człowiekowi pierwotnemu, żyjącemu w stanie natury. Wolność pierwotna jest posłuszeństwem wobec praw natury. W sferze społecznej odpowiada jej wolność jako posłuszeństwo woli powszechnej, przejawiającej się w prawie. W życiu osobistym wolność polega na wyrzeczeniu się sztucznych potrzeb.
\end{abstract}

Słowa kluczowe: Rousseau, Oświecenie, wolność

1. Wstęp. 2. Wolność pierwotna. 3. Wolność społeczna. 4. Wolność osobista. 5. Zakończenie.

\section{WSTĘP}

Problem ludzkiej wolności i jej natury odnaleźć można w niemal wszystkich rozprawach Jana Jakuba Rousseau. Świadczy to o wielkiej wadze, jaką genewski filozof przykładał do odpowiedzi na pytanie o wolność człowieka. Rousseau zanim zadał pytanie o to, czy człowiek jest wolny, badał, czym w istocie jest owa wolność. Jakże bowiem odpowiedzieć na pytanie o wolność, nie wiedząc, czym ona jest. Koniecznym jest odkrycie natury wolności, by można było mówić o wolności ludzkiej. Pytał więc nie tylko o to, czy człowiek jest wolny, a takie pytanie było typowe dla racjonalistów wieku Oświecenia, ale pytał też o to, na czym owa wolność ludzka polega, dostrzegając, że nie jest ona zjawiskiem dającym się w sposób jednoznaczny opisać, a problem wolności ludzkiej jest problemem bardziej złożonym niż to się jemu współczesnym filozofom wydawało.

Odpowiedź na pytanie o wolność człowieka jest bez wątpienia w myśli Rousseau specyficzna wobec innych ówczesnych odpowiedzi 
na to pytanie. Wolność ludzka, zdaniem genewskiego filozofa, winna być rozpatrywana w różnych kontekstach, a w zależności od kontekstu przybiera ona różne swoje oblicza. W niniejszym artykule opisze się trzy oblicza wolności wskazane przez Rousseau: wolność w znaczeniu pierwotnym, wolność w znaczeniu społecznym i wolność w znaczeniu osobistym. Stąd też w kolejnych punktach scharakteryzuje się każdą z wymienionych wyżej interpretacji wolności.

\section{WOLNOŚĆ PIERWOTNA}

Powszechnie znane są poglądy Jana Jakuba Rousseau na temat stanu pierwotnego rodzaju ludzkiego, w którym to stanie człowiek nie posiadał zdolności rozumowania, stąd też wszelkie jego działania były całkowicie zgodne z prawami natury, których władzy człowiek przeciwstawić się nie mógł. Człowiek posłuszny był prawom natury i działał zawsze zgodnie z nimi. Jak czytamy w Rozprawie o pochodzeniu i podstawach nierówności między ludźmi, człowiek w stanie pierwotnym wyszedł wprost $z$ rąk natury „głód syci pod dębem, pragnienie gasi w byle strumieniu, łoże znajduje u stóp tegoż drzewa, pod którym przed chwilą spożył posiłek”'. W innym miejscu wspomnianej rozprawy, czytamy: „Z powodu braku rozumnego zastanowienia człowiek pierwotny daje się zawsze na oślep porwać pierwotnemu, praludzkiemu uczuciu"2. Można zauważyć, że Rousseau uznawał całkowity determinizm odnośnie do ludzkich wyborów w stanie pierwotnym. Człowiek i jego działanie w stanie pierwotnym były całkowicie biologicznie zdeterminowane. Człowiekiem w stanie pierwotnym rządziła biologiczna konieczność, której przeciwstawić się nie mógł, która determinowała każdy wybór ludzki. Innymi słowy

1 Zob. J.J. Rousseau, Rozprawa o pochodzeniu i podstawach nierówności między ludźmi, w: tenże, Trzy rozprawy z filozofii społecznej, tłum. z fr. H. Elzenberg, PWN, Kraków 1956, 144.

2 Zob. tamże, 175. 
człowiek z konieczności był posłuszny prawom natury. Zdaniem Rousseau, to właśnie owo posłuszeństwo sprawiało, że człowiek w stanie pierwotnym był całkowicie wolny. $\mathrm{O}$ wolności bowiem nie decyduje według Rousseau możność wyboru, ale właśnie posłuszeństwo prawom, posłuszeństwo, które człowiek sam sobie narzuca, nawet jeśli jest ono koniecznością, a nie wyborem. Prawa natury, które rządziły życiem człowieka $\mathrm{w}$ stanie pierwotnym, były prawami wpisanymi w naturę każdego człowieka, tak że prawa te można zinterpretować jako prawa, które człowiek w stanie pierwotnym sam sobie w sposób konieczny narzucał i którym z konieczności był posłuszny. Stąd też w Rozprawie o nierórwności Rousseau napisał: "Chciałbym żyć i umrzeć wolny, tzn. tak posłuszny prawom, żeby nikt, ani ja sam, ani nikt inny - nie mógł zrzucić zaszczytnego ich jarzma, owego jarzma tak zbawiennego i miłego"3. Bez wątpienia prawa natury są prawami, których nikt zmienić nie może, a w stanie pierwotnym wszyscy jednakowo im podlegali, i nikt nawet nie mógł się im przeciwstawić. Zmieniło się to zdaniem Rousseau dopiero wtedy, gdy ludzie zaczęli korzystać ze zdolności rozumowania i tworzyć pierwsze społeczności.

Można więc uznać, że w stanie pierwotnym wolność człowieka polegała na posłuszeństwie wobec praw wpisanych przez Boga w naturę świata, w tym w naturę samego człowieka. Wolność w stanie pierwotnym to posłuszeństwo własnej naturze. Wolność taka w stanie pierwotnym realizowała się $\mathrm{w}$ sposób pełny $\mathrm{z}$ dwóch głównych powodów. Pierwszy to taki, że człowiek w stanie pierwotnym był niezależny od innych ludzi, od których niczego nie potrzebował i którzy niczego nie potrzebowali od niego. Drugi to taki, że człowiek nie posiadał zdolności rozumowania, która według genewskiego filozofa jest źródłem błędu w rozpoznawaniu naturalnych obowiązków człowieka. Można uznać, że zdaniem Rousseau człowiek jest naprawdę wolny, gdy zachowane są dwa warunki. Pierwszy - niezależność

3 Zob. tamże, 112. 
wobec innych ludzi, drugi - brak rozumowego zastanowienia, które odwodzi człowieka od wypełniania prawa naturalnego. Spełnienie tych dwóch warunków powoduje, że człowiek słucha tylko swojej natury, która nigdy nie wprowadza go w błąd, a tym samym, zdaniem Jana Jakuba Rousseau, człowiek jest w pełni wolny, mimo że przecież żadnego wyboru nie dokonuje. Możność dokonywania wyborów nie jest więc wyznacznikiem wolności.

Tu ujawnia się inna aniżeli typowa oświeceniowa koncepcja praw natury, które nie są u Rousseau prawami tożsamymi z prawami rozumu ludzkiego. To właśnie rozum człowieka jest, zdaniem genewskiego myśliciela, źródłem zaprzeczenia praw natury, źródłem tego, że człowiek przestał słuchać samego siebie. Wraz z wykształceniem się zdolności rozumowania człowiek utracił swoją wolność, gdyż paradoksalnie wraz z rozumem pojawiła się możliwość, by praw natury nie słuchać, a nieposłuszeństwo wobec praw natury jest jednoznaczne ze zniewoleniem. W bardzo obrazowy sposób Rousseau ukazał ten problem w Rozprawie o nierówności, napisał tam: pod wpływem rozumu człowiek ,zasklepia się w sobie, on to odcina go od wszystkiego, co go dręczy i trapi (...) można bezkarnie przed jego oknem zarżnąć jednego z jego bliźnich; on sobie ręce położy na uszach, coś niecoś sobie poargumentuje i buntującej się w nim naturze zakaże utożsamiać się z tym kogo mordują. Człowiek dziki jest pozbawiony tej podziwu wartej zdolności i z braku rozumnego zastanowienia daje się zawsze porwać na oślep, pierwotnemu, praludzkiemu uczuciu"'. W Rozprawie o naukach i sztukach czytamy natomiast: „Dziś (...) uprzejmość wciąż czegoś wymaga, przyzwoitość coś nakazuje, wciąż idzie się za zwyczajem, nigdy za swą własną naturą"

Co jednak Rousseau rozumiał pod pojęciem prawa natury? Sam wprost odpowiada na to pytanie w Rozprawie o nierówności. Pisze: „Zastanawiając się nad pierwszymi, najprostszymi czynnościami

4 Zob. tamże, 175.

5 Zob. tenże, Rozprawa o naukach i sztukach, w: tenże, Trzy rozprawy, dz. cyt., 13, 14. 
duszy człowieka, spostrzegam w niej jak mi się zdaje, dwa czynniki wcześniejsze niż rozum: jeden $\mathrm{z}$ nich to gorąca troska o własną każdego pomyślność i życie, drugi to naturalna odraza do zagłady albo cierpienia każdej istoty czującej, zwłaszcza zaś drugiego człowieka. $\mathrm{Z}$ połączenia i współdziałania w miarę możliwości naszego ducha tych dwóch czynników (...) zdają mi się płynąć wszystkie reguły z zakresu prawa naturalnego". Za pierwsze i fundamentalne prawo natury Rousseau, podobnie jak inni filozofowie francuscy tamtego okresu, uznał miłość samego siebie, tożsamą z dążeniem do samorealizacji każdego bytu, w tym też człowieka. Człowiek w stanie pierwotnym dążył przede wszystkim do zachowania swojego życia. kierowany pierwotnym impulsem. Ów impuls Rousseau nazywał uczuciem miłości ku własnej swej istocie, którego pochodną było uczucie litości, inaczej - uczucie miłości do innych istot czujących tak jak człowiek. Kierując się tymi uczuciami człowiek zawsze był posłuszny prawu natury, które nakazywało mu chronić siebie, swoje zdrowie, swoje życie oraz nie krzywdzić innych istot czujących. Działając w ten właśnie sposób, słuchał swojej natury, a tym samym był w pełni wolny, nie słuchał bowiem nikogo ani niczego, ale tylko samego siebie.

Reasumując - zdaniem Jana Jakuba Rousseau ludzie z natury swojej są wolni, to znaczy posłuszni prawom, które sami sobie narzucają. Dopiero z czasem wolność tę tracą, gdy przestają słuchać swojej natury a zaczynają słuchać innych ludzi, porównywać się z nimi, z nimi konkurować.

Wolność, jako że jest naturalną cechą człowieka, powinna też przysługiwać człowiekowi w stanie społecznym. Stąd wolność stała się dla Rousseau postulatem koniecznym do zrealizowania również poza stanem pierwotnym. Jednak w stanie społecznym wolność człowieka nie może być taka sama jak wolność w stanie pierwotnym,

6 Zob. tenże, Rozprawa o pochodzeniu i podstawach nierówności między ludźmi, w: tenże, Trzy rozprawy, dz. cyt., 133. 
gdyż w stanie społecznym człowiek ze względu na rozbudowane potrzeby, których samodzielnie nie jest już w stanie zrealizować, staje się zależny od innych ludzi, a tym samym przestaje być zdolny do wypełniania praw natury w taki sposób, w jaki czynił to w stanie pierwotnym. W Marzeniach samotnego wędrowca Rousseau napisał: „wszystkie naturalne skłonności, nie wykluczając chęci czynienia dobrze, przeniesione na grunt społeczny, albo tam rozwijane, nieroztropnie i bez wyboru, zmieniają swą naturę i często stają się szkodliwe, jak były pożyteczne w pierwszym przypadku”. W Umowie spotecznej czytamy: „Tak więc słodki głos natury nie jest już dla nas niezawodnym przewodnikiem". Dlatego poza stanem pierwotnym człowiek już nigdy wolny - w znaczeniu pełnego posłuszeństwa prawom natury i pełnej niezależności od innych - nie będzie. Jednak może być wolny również w stanie społecznym, ale wolność tę rozum musi oprzeć na innych podstawach.

\section{WOLNOŚĆ SPOŁECZNA}

Filozofowie epoki Oświecenia jednomyślnie twierdzili, że każdy człowiek ma prawo do wolności, a twierdzenie to wypływało z przekonania, że skoro w stanie natury wolność była naturalnym uprawnieniem każdego człowieka, musi ona być obecna również w życiu człowieka uspołecznionego. Naturalna wolność, w ujęciu Rousseau, taka jaka była w stanie pierwotnym, to wolność polegająca na niezależności jednego człowieka od drugiego i całkowitym posłuszeństwie prawom natury. Taka wolność nie jest jednak możliwa w społeczeństwie, gdzie z konieczności ludzie zależą od siebie nawzajem,

7 Zob. tenże, Marzenia samotnego wędrowca, tłum. z fr. E. Rzadkowska, Zakład Narodowy im. Ossolińskich, Wrocław 1983, 81.

8 Zob. tenże, Umowa społeczna oraz Uwagi o rządzie polskim, Przedmowa do Narcyza, List o widowiskach, List o Opatrzności, Listy moralne, List do arcybiskupa du Beaumont, Listy do Melesherbesa, tłum. z fr. B. Baczko, W. Bieńkowska, Pawłowska, A. Peretiatkowicz, J. Rogoziński, M. Staszewski, B. Strumiński, PWN, Warszawa 1966, 169. 
gdzie naturalne potrzeby człowieka zostały wyparte przez potrzeby sztuczne, a prawa natury realizować się mogą jedynie wtedy, gdy ugruntowane są prawami stanowionymi. Uznając, że człowiek nie może być wolny w znaczeniu całkowitej niezależności od innych i zależności jedynie od praw natury, Rousseau na nowo zinterpretował pojęcie ludzkiej wolności, tym razem w kontekście społecznym.

Przypomnijmy, że w stanie pierwotnym człowiek z natury był wolny, a jego wolność polegała na pełnym posłuszeństwie prawom natury. Ten rodzaj wolności został bezpowrotnie przez człowieka utracony z dwóch powodów: pierwszy to zdobycie przez człowieka zdolności rozumowania, które - jak twierdził Rousseau - zagłusza naturę, przekształcając uczucie miłości ku własnej istocie w uczucie miłości własnej: drugi to uzależnienie się człowieka od innych ludzi. Zdaniem Jana Jakuba Rousseau człowiek nie może odzyskać pełnej wolności, takiej, jaką posiadał w stanie pierwotnym, gdyż nie jest możliwe do tego stanu powrócić, to znaczy pozbyć się zdolności rozumowania oraz stać się na powrót niezależnym od innych ludzi. Innymi słowy człowiek przestał być samotną wyspą, a stał się elementem większej całości, od której stał się zależny w swoim życiu. Nie znaczy to jednak, że człowiek nie może być wolny. Wolność, jaką może zdobyć w stanie społecznym, musi jednak zmienić swoje oblicze, mimo że wzorcem dla niej jest wolność, jaką człowiek posiadał w stanie pierwotnym. I tak też wolność w znaczeniu społecznym oznacza również posłuszeństwo prawu, ale prawu stanowionemu, a nie tylko prawu naturalnemu. Wolność w znaczeniu społecznym, czy też jak można ją nazwać wolność polityczna, zdaniem Rousseau, polega na całkowitej zgodzie i całkowitym posłuszeństwie prawom stanowionym. Opis tego rodzaju wolności odnaleźć można głównie w Umowie spotecznej oraz w Ekonomii politycznej. ${ }^{9}$ Wolność w tym znaczeniu, według niego, zawiera się w całości w czynnościach

9 Posłuszeństwo prawom stanowionym w racjonalizmie Rousseau jest jednocześnie posłuszeństwem własnej woli. Wszystkie prawa w państwie nie są nadane człowiekowi 
prawodawczych. W niniejszym punkcie przeanalizuje się problem wolności politycznej jako postulatu społecznego.

Powiedziano już, że wolność człowieka w stanie społecznym polega na posłuszeństwie prawom stanowionym, ale jedynie takim prawom, które są odbiciem woli powszechnej. Wola powszechna, tak jak rozumiał ją Rousseau w kontekście rozważanego tu problemu wolności człowieka, była wolą wyrażającą dobro wspólne zrzeszonych w społeczeństwie ludzi. Należy zaznaczyć, że jego koncepcja woli powszechnej zakłada powszechność i zgodność ludzkich pragnień i celów. Prawa oparte na woli powszechnej są więc prawami, które wiążą interesy wszystkich obywateli, które sprzyjają zawsze dobru publicznemu, które są prawami najsprawiedliwszymi, które w końcu prowadzą do doskonalenia każdego obywatela $z$ osobna i wszystkich obywateli razem. Stąd Rousseau napisał: „Ta zaś wola powszechna, która zawsze zmierza ku zachowaniu i dobrobytowi zarówno całości, jak i każdej części i jest źródłem praw, stanowi dla wszystkich członków państwa, wskaźnik tego, co sprawiedliwe i niesprawiedliwe"10. Wola powszechna w społeczeństwie staje się źródłem praw będących gwarancją dla prawa natury i dlatego to jej w społeczeństwie ludzie podlegają w pierwszym rzędzie. Tak jak człowiek pierwotny podlegał bezpośrednio prawom natury, tak człowiek uspołeczniony podlegać ma bezpośrednio woli powszechnej. Tak jak owo bezpośrednie podporządkowanie się prawom natury w stanie pierwotnym było gwarantem samorealizacji człowieka w tym stanie, tak posłuszeństwo woli powszechnej jest gwarantem samorealizacji człowieka w stanie społecznym, która to samorealizacja zależna jest od dobrobytu całości społeczeństwa. Odkąd człowiek stał się istotą społeczną, wszelkie działania muszą być kierowane wolą powszechną.

arbitralnie, ale pochodzą z nakazu woli powszechnej, która jest wolą rozumną, każdego członka społeczeństwa w nim zrzeszonego.

10 Zob. tenże, Ekonomia polityczna, w: tenże, Trzy rozprawy, dz. cyt., 289. 
Bez posłuszeństwa kierownictwu woli powszechnej, nie ma w stanie społecznym wolności dla nikogo.

Pierwszym prawem opartym na woli powszechnej, według Jana Jakuba Rousseau, jest umowa społeczna. Umowa społeczna występuje jako pierwsze prawo stanowione przez samych ludzi dla nich samych. Jest ona, jak pisze, „formą stowarzyszenia, które by broniło i chroniło całą wspólną siłą osobę i dobra każdego jej członka i dzięki której każdy, łącząc się ze wszystkimi, słuchałby jednak tylko siebie i pozostał równie wolny jak przedtem”. Ten rodzaj wolności jest możliwy tylko wtedy, kiedy człowiek rezygnuje z woli indywidualnej na rzecz woli powszechnej i w akcie przystąpienia do umowy społecznej „wraz ze wszystkimi swoimi uprawnieniami oddaje się całej społeczności”11. Przez ten akt zrzeczenia się wszystkich swoich uprawnień człowiek czyni siebie w pełni wolnym obywatelem społeczności, gdyż sam na siebie nakłada prawa, będące wynikiem woli powszechnej, która jest jednocześnie jego własną wolą i zarazem wolą całego społeczeństwa. Innymi słowy człowiek przystępując do umowy społecznej zaczyna myśleć i działać jako członek całości, a nie jako odrębna jednostka szukająca korzyści kosztem innych.

Jan Jakub Rousseau twierdził, że gdyby człowiek pozostał w stanie pierwotnym, nie potrzebowałby żadnych praw stanowionych, żadnych umów. Natura człowieka pierwotnego realizuje się przez naturalne prawa przyrody. Natura człowieka cywilizowanego potrzebuje praw stanowionych, które są jedynie układem między ludźmi i są gwarancją istnienia praw naturalnych. W tym sensie wolność, jaką zapewniają prawa, nie jest wolnością naturalną, ale jest wolnością obywatelską i jest jedyną wolnością, którą człowiek w społeczeństwie może posiadać. Prawa gwarantują, że wolność i równość będą udziałem człowieka w państwie, natomiast nie sprawiają, że wolność i równość stają się identyczne z tymi otrzymanymi od natury. Naturalne potrzeby człowieka są dostosowane do stanu pierwotnego,

11 Zob. tenże, Rozprawa o naukach i sztukach, art. cyt., 22. 
natomiast w stanie społecznym muszą ulec takiemu przeobrażeniu, aby były dostosowane do stanu społecznego.

Stan społeczny wymaga więc, by wolności nie utożsamiać z całkowitą niezależnością człowieka od człowieka. Owa niezależność w stanie społecznym doprowadziłaby bowiem do zguby nie tylko samych ludzi, ale i całe państwo. Wolność w stanie społecznym Rousseau utożsamił z ograniczeniami narzuconymi przez wolę powszechną, która jest źródłem praw. One to dają człowiekowi poczucie pewności, że granice jego wolności nie zostaną mu odebrane i będą poszanowane przez innych, a tym samym dają gwarancję jednostce, że mimo uzależnienia od innych będzie mogła realizować się na równi z innymi. Człowiek tym sposobem może wyzbyć się zniewalającego strachu przed drugim człowiekiem, który towarzyszyłby mu, gdyby nie było praw. „Nikt z was nie jest tak nieoświecony - pisał Rousseau - by nie wiedział, że tam, gdzie się kończy moc ustaw i autorytet ich obrońców, tam dla nikogo nie ma już ani bezpieczeństwa, ani wolności"12. Ograniczenia związane z faktem wspólistnienia $z$ innymi nie są oznaką braku wolności, jeśli związki te są regulowane przez prawa, które formułowane są na mocy woli powszechnej. Brak takich praw prowadziłby do tyranii silnych nad słabymi, a w konsekwencji do całkowitego braku wolności dla wszystkich, gdyż jedni byliby niewolnikami drugich, słabi niewolnikami tyranów, tyrani niewolnikami tych pierwszych, od których nieustannie potrzebowaliby usług.

\section{WOLNOŚĆ OSOBISTA}

Trzecim rodzajem wolności, o jakiej wspomina Rousseau, jest wolność osobista każdego człowieka. Jest ona wolnością całkowicie niezależną od czynności prawodawczych, a polega na niezależności człowieka od sztucznych potrzeb tworzonych przez samych ludzi na

12 Zob. tenże, Rozprawa o pochodzeniu i podstawach nierówności między ludźmi, art. cyt., 119, 120. 
swoje nieszczęście i ku własnemu zniewoleniu. Ten rodzaj wolności Rousseau opisał szczególnie w Emilu oraz w swojej pierwszej rozprawie $O$ naukach $i$ sztukach, w której wskazał na źródła ludzkiego zniewolenia w tym zakresie.

Zdaniem genewskiego filozofa źródłem zniewolenia w charakteryzowanym tu znaczeniu jest przede wszystkim przekroczenie przez człowieka granicy między swoimi potrzebami i możliwościami ich zrealizowania. Mając coraz nowe potrzeby, człowiek jednocześnie ma coraz mniej siły do tego, by samodzielnie je realizować, a tym sposobem z konieczności staje się niewolnikiem ludzi, od których potrzebuje pomocy, oraz niewolnikiem swoich potrzeb, z których zrezygnować nie umie. Rousseau wskazuje nadto, że człowiek potrzebując innych ludzi do zaspokajania swoich potrzeb, tym samym czyniąc siebie ich niewolnikiem, jednocześnie niewolnikami czyni innych. W ten sposób panowanie staje się niewolą. Stąd w Emilu Rousseau napisał: „Człowiek uspołeczniony rodzi się, żyje i umiera w niewoli"13.

Charakteryzując ludzką wolność w znaczeniu wolności osobistej, Rousseau odwoływał się do stanu natury, czyli do tego stanu, gdzie o życiu człowieka i jego postępowaniu rozstrzygała sama jego natura, by na takim tle ukazać kondycję człowieka jemu współczesnego. Człowiek w stanie pierwotnym posiadał jedynie takie potrzeby, które niezbędne mu były do zachowania życia. Nie pragnął więcej, gdyż nie był świadomy tego, że istnieje coś więcej ponad pożywienie i schronienie przed zimnem lub upałem. Wiedział jedynie, że kiedy jest głodny, musi zdobyć pożywienie, kiedy mu zimno, musi zdobyć schronienie, kiedy coś lub ktoś zagraża jego życiu, musi się bronić i ta wiedza wystarczała mu w zupełności do życia i do szczęścia. „Wynika stąd - pisał Rousseau - że skoro człowiek dziki pragnie tylko tych rzeczy, które zna, zna zaś tylko te, które posiąść albo całkiem jest

13 Zob. tenże, Emil, czyli O wychowaniu, t. 1, tłum. z fr. W. Husarski, E. Zieliński, Wydawnictwo Naukowego Towarzystwa Pedagogicznego, Warszawa 1930, 15. 
w jego mocy, albo które mu przychodzą bez trudu, nie może być nic tak doskonale spokojnego, jak jego dusza i nic równie ograniczonego, jak jego umysł"14. Jeżeli człowiek w stanie pierwotnym miał jedynie potrzeby niezbędne, by zachować życie, a sił miał wystarczająco dużo, by te potrzeby zrealizować, to wniosek, jaki z tego płynie, może być tylko jeden, że człowiek taki nie ograniczał wolności drugiego człowieka, a jego wolność nie była ograniczana przez innych. Człowiek $\mathrm{w}$ stanie pierwotnym był zdany wyłącznie na siebie. Zdany tylko na siebie i na swoją siłę, robił tylko to, co było konieczne, by zachować swoje życie. Był więc całkowicie wolny, nie ograniczony przez łaskę i niełaskę drugiego człowieka, nie ograniczony przez potrzeby, których nie mógłby sam zrealizować. Między ludźmi nie było żadnych bliższych relacji, każdy żył, podlegając tym samym prawom natury i działał zgodnie z nimi, słuchając tylko siebie.

Prawa natury człowiek w stanie pierwotnym wypełniał $\mathrm{z}$ łatwością, niewiele bowiem posiadał potrzeb, tak że bez problemu starczało mu sił na ich realizację. Nie oczekiwał pomocy od innych, tak jak inni nie szukali pomocy u niego. Jeśli ludzie sobie pomagali, to tylko kierowani pierwotnym uczuciem litości, nie oczekując w zamian żadnych korzyści. To miało zmienić się w stanie społecznym, kiedy to potrzeby człowieka zaczęły się zwiększać, tak że człowiek zaczął potrzebować innych do ich wypełnienia, przez co zaczął być zależny od innych i innych zaczął wykorzystywać dla ich zaspokojenia. Dodajmy za Rousseau - potrzeb całkiem sztucznych i niekoniecznych do samorealizacji. Jego zdaniem, zwiększały się one wraz z rozwojem zdolności rozumowania, rozwojem nauki, sztuki, techniki. Im więcej

14 Zob. tenże, Rozprawa o pochodzeniu i podstawach nierówności między ludźmi, art. cyt., 262. „Pragnąć bowiem lub lękać się jakiejś rzeczy można tylko albo ze względu na wyobrażenia, jakie się o niej posiada, albo też idąc za prostym popędem natury; człowiek zaś dziki, któremu brak jest wiadomości niemal o wszystkim, odczuwa namiętności niemal wyłącznie drugiego rodzaju; pragnienia jego nie dalej sięgają niż jego pragnienia fizyczne; jedyne na świecie znane mu dobra - to pożywienie, samica i wypoczynek; jedyne nieszczęścia, jakich się lęka, to ból i głód”. Zob. tamże, 156. 
potrzeb, tym mniej sił, im mniej sił, tym bardziej człowiek pogrążał się w niewoli. W końcu doszedł do takiego momentu, gdy nie posiadał już nawet tyle sił, aby zaspokoić swoje naturalne potrzeby, nie wspominając już o tych, które są owocem rozwoju nauki i sztuki. Stąd znamienne zdanie zapisane w Umowie spotecznej: „Człowiek urodził się wolny, a wszędzie jest w okowach"15.

Człowiek w stanie społecznym jest zdaniem Jana Jakuba Rousseau przede wszystkim niewolnikiem zbytecznych dóbr, których zdobycie obarczone jest potrzebą pomocy od innych. Porównując człowieka $\mathrm{w}$ stanie jego pierwotnej natury z człowiekiem, którego natura została zniekształcona za sprawą postępu w naukach i sztukach, a tych źródłem był ludzki rozum, Rousseau napisał: człowiekowi temu „z początku chodzi o rzeczy niezbędne, potem o nadmiar i zbytek; potem muszą być jeszcze rozkosze, potem wielkie bogactwa, potem poddani, potem jeszcze i niewolnicy; nie ma ani chwili wytchnienia; a co ze wszystkiego najosobliwsze, to, że im mniej naturalne i palące są jakieś potrzeby, tym bardziej rośnie namiętność i, co gorsza, możność jej nasycenia; i tak po długich okresach pomyślności, po roztrwonieniu wielu skarbów i pogrążeniu wielu ludzi w rozpaczy i nędzy, bohater mój na zakończenie wyrżnie wszystkich i zostanie na placu jako jedyny pan świata. Taki jest w skrócie obraz moralny, jeśli nie życia ludzkiego, to utajonych pragnień serdecznych, każdego cywilizowanego człowieka”16. „Człowiek z wolnego i niezależnego, jakim był dotąd - pisze Rousseau w innym miejscu - jest teraz oto za sprawą mnóstwa nowych potrzeb, podległy całej, że tak powiem naturze, a zwłaszcza zaś reszcie ludzi, których się w pewnym sensie staje niewolnikiem tam nawet, gdzie się staje ich panem. W bogactwie potrzebuje ich usług, w biedzie - pomocy"17.

15 Zob. tenże, Umowa społeczna, tłum. z fr. A. Pieretiatkowicz, „Antyk”, Kęty 2002, 11.

16 Zob. tenże, Rozprawa o pochodzeniu i podstawach nierówności między ludźmi, art. cyt., $244,245$.

17 Zob. tamże, 202. 
Jedynym sposobem na pozbycie się owych kajdan, które zniewalają człowieka, jest zdaniem Rousseau ograniczenie potrzeb do minimum. Człowiek nie może już wrócić do stanu pierwotnego, stanu pełniej niezależności i wolności, ale może odzyskać wolność osobistą, gdy ograniczy swoje potrzeby do tych najbardziej naturalnych. Taki pogląd sprawił, że zarzucano Rousseau, jak to sam stwierdził, iż remedium na kondycję człowieka XVIII wieku sprowadził do „wygnania nauki i uczonych, spalenia bibliotek, zamknięcia Akademii, kolegiów, Uniwersytetów i pogłębieniu się w barbarzyńskich czasach pierwotnych". Rousseau sprzeciwiał się takiej interpretacji jego myśli. Pisał: „nigdy nie pomyślałem ani nie napisałem żadnego słowa z całego tego wywodu i nie można sobie wyobrazić niczego bardziej przeciwnego mojemu systemowi, niż ta absurdalna doktryna, którą mi się łaskawie przypisuje" ${ }^{\prime 18}$. Genewski myśliciel wierzył, że może istnieć społeczeństwo, w którym człowiek pozostanie wolny, społeczeństwo takie, jakie opisał w Nowej Heloizie - pełne spontanicznej zabawy prostego ludu. Społeczeństwo ludzi wolnych - podobnych do Emila, bohatera jego podręcznika wychowania. Społeczeństwo ludzi rozumnych, którzy zdolni byliby podążać za wolą powszechną dla dobra swojego oraz dobra wszystkich ludzi. Rousseau zachował więc $\mathrm{w}$ pewnym sensie optymizm swojej epoki.

\section{ZAKOŃCZENIE}

Jan Jakub Rousseau wyróżnił trzy rodzaje wolności człowieka: wolność pierwotną, wolność społeczną i wolność osobistą. Człowiek według niego nie może powrócić do takiej wolności, jaką miał w stanie pierwotnym, natomiast może być wolny w społeczeństwie, przystępując do umowy społecznej i będąc w pełni posłusznym woli powszechnej. Może też zachować wolność osobistą, ograniczając swoje potrzeby do tych, których spełnienie nie wymaga pomocy innych ludzi.

18 Zob. tenże, Przedmowa do Narcyza, w: Umowa społeczna oraz Uwagi, dz. cyt., 313. 
Powyższe przemyślenia na temat wolności w pismach Jana Jakuba Rousseau nie wyczerpują tego zagadnienia, które jest na tyle obszerne, że mogłoby posłużyć jako problem większej publikacji. Zauważyć należy, że interpretatorzy Rousseańskiego problemu wolności dokonali wielu uproszczeń, które mogłaby wyjaśnić głębsza analiza tematu.

\section{BIBLIOGRAFIA}

Rousseau J.J., Emil, czyli O wychowaniu, tłum. z fr. W. Husarski, E. Zieliński, Wydawnictwo Naukowego Towarzystwa Pedagogicznego, Warszawa 1930.

Rousseau J.J., Marzenia samotnego wędrowca, tłum. z fr. E. Rzadkowska, Zakład Narodowy im. Ossolińskich, Wrocław 1983.

Rousseau J.J., Trzy rozprawy z fllozofii spotecznej, tłum. z fr. H. Elzenberg, PWN, Kraków 1956.

Rousseau J.J., Umowa spoteczna oraz Uwagi o rzadzie polskim, Przedmowa do Narcyza, List o widowiskach, List o Opatrzności, Listy moralne, List do arcybiskupa du Beaumont, Listy do Melesherbesa, tlum. z fr. B. Baczko, W. Bieńkowska, M. Pawłowska, A. Peretiatkowicz, J. Rogoziński, M. Staszewski, B. Strumiński, PWN, Warszawa 1966.

Rousseau J.J., Umowa spoteczna, tłum. z fr. A. Peretiatkowicz, „Antyk”, Kęty 2002.

\section{HUMAN FREEDOM ACCORDING TO JEAN-JACQUES ROUSSEAU}

Abstract. Jean-Jacques Rousseau defended human freedom in individual and social dimensions. The basis for human freedom was natural freedom, appropriate to the primitive man, who lived in a state of nature. For Rousseau the original freedom was obedience to the laws of nature. In the social sphere it corresponded to the freedom as obedience to the general will, which was manifested in law. In the life of particular person freedom meant renouncing artificial needs.

Keywords: Rousseau, Enlightenment, freedom

SYLWIA ESTERA ZAWADZKA

s.zawadzka@uksw.edu.pl

Uniwersytet Kardynała Stefana Wyszyńskiego w Warszawie, Instytut Filozofii

Wóycickiego 1/3, 01-938 Warszawa

DOI 10.21697/spch.2016.52.1.06 